\title{
COMPARATIVE STUDY: DISTRIBUTING FE TABLET AND FE TABLET COMBINED WITH MILK AND VITAMIN C
}

\author{
Badriah, Omay Rohmana \\ Nursing Program of Poltekkes - Kemenkes Tasikmalaya, Cirebon, Indonesia \\ Correspondence: badriah_crb@yahoo.co.id/badriahbaran@gmail.com
}

\begin{abstract}
The daily intake of iron (Fe) is needed to exchange the loss through feces, urine, and skin in the body. The basal loss is approximately around $14 \mu \mathrm{g} / \mathrm{kg}$ of body weight per day, or nearly equal to $0.08 \mathrm{mg}$ of iron for female. Woman in childbearing age lose iron through menstrual periods. Some study have shown that the mean of blood loss during menstruation ranged between 25 to $30 \mathrm{cc}$ per month. The amount of iron loss is about $12.5-15 \mathrm{mg}$ per month or $0.4-0.5 \mathrm{mg}$ per 28 days. If we combined it with basal loss, the total of iron loss is approximately $1.25 \mathrm{mg} /$ day. If we calculated based on the frequency of menstrual blood loss distribution, $2.5 \%$ of women need more than $2.4 \mathrm{mg}$ iron per day. (E.M DeMaeyer, 1995). The aim of this study is to determine the difference between hemoglobin levels in Fe tablets and in the combination of Fe tablets with milk and vitamin $\mathrm{C}$ towards students. The experimental method with pretest and post-test in control group was used in this study. The sample was divided into three groups, whereby group 1 was given Fe tablet and milk, group 2 was supplemented with combination of vitamin $\mathrm{C}$, and the group 3 was given Fe tablet and mineral water. The respondents who were given Fe tablet + Milk had increased an average hemoglobin $(\mathrm{Hb})$ level for about $1.5 \mathrm{~mm} / \mathrm{dl}$, respondents who were given Fe tablet + Vitamin $\mathrm{C}$ had increased an average hemoglobin $(\mathrm{Hb})$ for about $1.3 \mathrm{~mm} / \mathrm{dl}$, and respondents who were given $\mathrm{Fe}+$ mineral water (control) had increased an average hemoglobin $(\mathrm{Hb})$ for about 1.29 $\mathrm{mm} / \mathrm{dl}$. The proportion of respondents given Fe tablets + Milk is $21,1 \%$, Fe tablet + Vitamin $\mathrm{C}$ is $15.2 \%$, and Fe tablet + mineral water is $15.1 \%$. There is no significant differences among the treatment groups of Fe tablet + milk, Fe tablet + Vitamin $\mathrm{C}$, and Fe tablet + mineral water. The value of the test is 0.0939 greater than 0.05 . The consumption of Fe tablet can prevent anemia for students and improve the cross-sectoral cooperation in programing the distribution of Fe tablet itself, especially to female students in the school.
\end{abstract}

Keywords: Fe tablets, milk, vitamin

\section{INTRODUCTION}

The iron daily intake is needed to replace the loss through feces, urine, and skin. The basal loss is approximately around $14 \mu \mathrm{g} / \mathrm{kg}$ of body weight per day, or nearly equal to $0.08 \mathrm{mg}$ of iron for female. Some studies have shown that the mean of blood loss during menstruation ranged between 25 to $30 \mathrm{cc}$ per month. This amount of iron loss is about $12.5-15 \mathrm{mg}$ per month or 0.4-0.5 mg per 28 days. If we combined it with basal loss, the total of iron loss is approximately $1.25 \mathrm{mg} /$ day (Maeyer, 1995).

Teenagers who lose blood through menstruation will replace the plasma fluid within 1-3 days. However, it will lower the concentration of erythrocyte cells in the 
body. Besides, if the second bleeding does not occur, the concentration of the erythrocyte will turn into normal within 3-6 weeks (Guyton, 1991). During adolescence age, a person will experience a rapid physical growth. For females, the peak growth velocity occurs approximately 12-18 months before the first menstruation, or around the age of 10-14 years old. The growth of stature continues for up to 7 years after menstruation. The biological processes of this period (puberty) are characterized by rapid growth of height, weight, the changes of tissue composition, and the changes in primary and secondary sexual characteristics. Therefore, the group of young women has the greatest risk in experiencing anemia since the need of $\mathrm{Fe}$ is also increased, especially due to the rapid growth of adolescents (Finanda, 2016).

Bandung Public health office distributed free Fe tablet for female students. "Pencanangan pemberian tablet Fe pada remaja putri", this program is focused on young girls to get Fe tablet or blood boosted tablet. According to Rosye Aridian, the distribution of tablets to adolescents in puberty phase, in which the $8^{\text {th }}$ and $11^{\text {th }}$ grade students, is a program conducted by Bandung Public Health Office and Bandung Education Office.

Cirebon has implemented a program in distrubuting Fe tablets to adolescents in school. Based on preliminary study at SMPN 9 Kota Cirebon, the Fe tablet program has been run, but no studies have stated the result of the program whether there is any change of students hemoglobin level or not. The result from the study conducted by Wibowo (2010) at SDN Klego Pekalongan has showed a significant improvement of hemoglobin level in the value of 0,000 .

Anemia can give a negative impact to students' achievements. Anemia can decrease the concentration of learning due to lack of oxygen. The lack of oxygen is 
caused by the low levels of hemoglobin that decrease the oxygenation in the central nerve system (Muchtar, 2000). Iron deficiency in anemia can also cause several symptoms, such as fatigue, lethargy and dizziness. Those symptoms can also cause the growth disturbances, lower the immune system, interfere the cognitive function and retard the development of psychomotor (Lubis et al, 2008).

The distribution of adolescent population is high, and it will greatly affect the population growth in the future. Even though they are still in school, they will soon enter the productive age. Therefore, they need to get serious attention since the future of the nation is on their hands. The attention itself can be given in form of Fe tablets distributions. The distribution of Fe tablets can increase the hemoglobin levels in the blood and greatly influence in the process of iron absorption in intestine. Several factors, including the distribution of milk and vitamin $\mathrm{C}$, can help the absorption process. The composition of iron in milk is about $+4 \mathrm{mg}$ or $40 \mathrm{gr}$, but it is strongly related to one of the homologous proteins with ferritin called lactoferrin. It helps the body in transporting iron to receptors in the intestine and is associated with the absorption itself (Devlin, 1992). The vitamin C is needed to increase the absorption process of iron in the body. The increased consumption of vitamin $C$ by $25,50,100$, and $250 \mathrm{mg}$ can increase iron absorption by 2, 3, 4, and 5 times (Wirakusumah, 1999).

Based on the description above, it is necessary to conduct a research by testing the consumption of $\mathrm{Fe}$ tablets (as the program has been running), whether it can increase the hemoglobin levels in students, then compare it with the consumption of Fe tablets combined with milk and vitamin $\mathrm{C}$. The title of the research is "Comparative Study: Distributing Fe Tablet and Fe Tablet Combined with Milk and Vitamin C To SMPN 09 Students in Cirebon 2017." 


\section{METHODS}

The type of research includes experimental research with a pretest-posttest approach and control group (Soekidjo Notoatmojo, 2005). The sample was divided into three groups, in which group 1 was given Fe tablet and milk, group 2 was given combination of vitamin $\mathrm{C}$, and the group 3 was given Fe tablet and mineral water.

\begin{tabular}{cccc}
\hline Group I & 01 & X1 & 02 \\
\hline Group II & 01 & X2 & 02 \\
\hline Group III & 01 & X3 & 02 \\
\hline
\end{tabular}

Note:
$01:$ Hb examination before treatment
$02:$ Hb examination after treatment
$\mathrm{X} 1$ : treatment by giving Fe tablet and milk
$\mathrm{X} 2$ : treatment by giving Fe tablet and vitamin $\mathrm{C}$
$\mathrm{X} 3$ : treatment by giving Fe tablet and Placebo

Population is the whole object of research or object under the study (Notoatmojo, 2010). The population in this research were 50 students who have experienced anemia at SMPN 09 .

The research sample is the representation of population used as a source of information in the data to answer the research problems (Pratik, 2003). The amount of the sample was determined using the formula $(\mathrm{t}-1)(\mathrm{r}-1)>15$, in which $\mathrm{t}$ is the treatment group and $r$ is the replication (Budijanto, 2015). In this research there are 3 treatment groups, then the sample amount is $(3-1)(r-1)>5$, so $r=(15 / 3-1)+1$, and the result is 
8.5. From the calculation, the replication of each treatment group is 8.5 and is roundup into 9. Thus, the overall sample is 27 people. The sampling technique is simple random sampling. If any respondent resigns, the reserve sample is determined by the formula $1 /(1-f)$, in which $\mathrm{f}$ is the proportion of missing experimental unit.

\section{RESULTS}

The "Comparative Study: Distributing Fe Tablet and Fe Tablet Combined with Milk and Vitamin C to SMPN 09 Students in Cirebon" has been conducted. So does the first measurement and data collection (pre-invention) and the second (post-intervention).

The results of measurement, data analysis, and discussion will be described as follows:

Measurements

Treatment group for Fe tablets and Milk

Table 1The Measurement of $\mathbf{H b}$ Level in Pre and Post Intervention in Treatment Group for Fe Tablets and Milk in SMPN 09 Cirebon

\begin{tabular}{|c|c|c|c|c|c|}
\hline No & Student Name & $\begin{array}{l}\text { Hb Pre Int } \\
\text { (Mm/DI) }\end{array}$ & $\begin{array}{l}\text { Hb Post Int } \\
\text { (Mm/DI) }\end{array}$ & $\begin{array}{l}\text { Hb Gain } \\
\text { (Mm/DI) }\end{array}$ & $\%$ \\
\hline 1 & AT & 8.5 & 10.9 & 2.4 & 28.2 \\
\hline 2 & LU & 7.1 & 10.8 & 3.7 & 52.1 \\
\hline 3 & SIL & 11.4 & 12.4 & 1 & 8.8 \\
\hline 4 & $\mathrm{~F}$ & 11.8 & 12.5 & 0.7 & 5.9 \\
\hline 5 & TPS & 10.1 & 9.9 & -0.2 & -2.0 \\
\hline 6 & $\mathrm{~J}$ & 5.4 & 9.8 & 4.4 & 81.5 \\
\hline 7 & AM & 9.2 & 10.6 & 1.4 & 15.2 \\
\hline 8 & VV & 11.1 & 10.3 & -0.8 & -7.2 \\
\hline \multirow[t]{3}{*}{9} & RO & 10.9 & 11.7 & 0.8 & 7.3 \\
\hline & Total & & & 13.4 & 189.9 \\
\hline & Average & & & 1.5 & 21.1 \\
\hline
\end{tabular}

respondents who were given Fe tablets and milk, have increased of $1.5 \mathrm{~mm} / \mathrm{dl}(21.2 \%)$.

One of the students had the highest hemoglobin levels, in which $5.4 \mathrm{~mm} / \mathrm{dl}$ before treatment and $9.8 \mathrm{~mm} / \mathrm{dl}$ after treatment $(81.5 \%)$. 
Treatment group for Fe tablets and Vitamin C

Table 2 The measurement of $\mathbf{H b}$ level in Pre and Post Intervention in Treatment Group for Fe Tablets and Vitamin C in SMPN 09 Cirebon

\begin{tabular}{clcccc}
\hline No & Student Name & $\begin{array}{c}\text { Hb Pre Int } \\
(\mathbf{M m} / \mathbf{D l})\end{array}$ & $\begin{array}{c}\text { Hb Post Int } \\
(\mathbf{M m} / \mathbf{D l})\end{array}$ & $\begin{array}{c}\text { Hb Gain } \\
(\mathbf{M m} / \mathbf{D l})\end{array}$ & $\%$ \\
\hline 1 & SW & 11.1 & 11.8 & 0.7 & 6.3 \\
2 & DM & 10.4 & 10.7 & 0.3 & 2.9 \\
3 & SMT & 10 & 9.9 & -0.1 & -1.0 \\
4 & KTA & 6.7 & 10.7 & 4 & 59.7 \\
5 & DS & 9.5 & 10.9 & 1.4 & 14.7 \\
6 & SN & 11.4 & 12.7 & 1.3 & 11.4 \\
7 & AFA & 11.5 & 12.4 & 0.9 & 7.8 \\
8 & TR & 9.8 & 11.7 & 1.9 & 19.4 \\
9 & FDL & 8.6 & 9.9 & 1.3 & 15.1 \\
\hline & Total & & & 11.7 & 136.4 \\
& Average & & & 1.3 & 15.2 \\
\hline
\end{tabular}

Based on the table above, it can be concluded that the hemoglobin of respondents who were given $\mathrm{Fe}$ tablets and vitamin $\mathrm{C}$, have increased of $1.3 \mathrm{~mm} / \mathrm{dl}$ (15.2\%). One of the students had the highest hemoglobin levels, in which $6.7 \mathrm{~mm} / \mathrm{dl}$ before treatment and $10.7 \mathrm{~mm} / \mathrm{dl}$ after treatment $(59.2 \%)$.

Treatment group for Fe tablets and Mineral Water

Table 3 The measurement of $\mathrm{Hb}$ level in Pre \& Post Intervention in treatment group for Fe tablets and Mineral Water in SMPN 09 Cirebon

\begin{tabular}{llrrrr}
\hline No & Student Name & $\begin{array}{c}\text { Hb Pre } \\
\text { Int } \\
(\mathbf{M m} / \mathbf{D l})\end{array}$ & $\begin{array}{c}\text { Hb Post } \\
\text { Int(Mm/Dl) }\end{array}$ & $\begin{array}{c}\text { Hb Gain } \\
(\mathbf{M m} / \mathbf{D l})\end{array}$ & \multicolumn{1}{c}{$\%$} \\
\hline 1 & LDA & 10.5 & 12.2 & 1.7 & 16.2 \\
2 & RS & 10.2 & 12.8 & 2.6 & 25.5 \\
3 & VPH & 9.9 & 12 & 2.1 & 21.2 \\
4 & SM & 8.7 & 8.7 & 0 & 0.0 \\
5 & SIA & 10 & 10.4 & 0.4 & 4.0 \\
6 & S & 6.8 & 9.5 & 2.7 & 39.7 \\
7 & HS & 6.1 & 7.5 & 1.4 & 23.0 \\
8 & FH & 11.5 & 12 & 0.5 & 4.3 \\
9 & DA & 10.8 & 11 & 0.2 & 1.9 \\
\hline & Total & & & 11.6 & 135.7 \\
& Average & & & 1.29 & 15.1 \\
\hline
\end{tabular}


Based on the table above, it can be concluded that the hemoglobin of respondents who were given Fe tablets and mineral water, have increased of $1.29 \mathrm{~mm} / \mathrm{dl}$ $(15.1 \%)$.

The Average Comparison of Measurement Results for Treatment Group of Fe tablets and milk, Fe tablets and vitamin $\mathrm{C}$, and Fe tablets and mineral water.

Tabel 4 The Average Comparison of Measurement Results for Treatment Group on Fe tablets and milk, Fe tablets and vitamin $\mathrm{C}$, and $\mathrm{Fe}$ tablets and mineral water in SMPN 09 Kota Cirebon

\begin{tabular}{clcc}
\hline No & \multicolumn{1}{c}{ Treatment Group } & $\begin{array}{c}\text { The average } \\
\text { Hb Gain } \\
(\mathbf{m m} / \mathbf{d l})\end{array}$ & \% \\
\hline 1. & Fe tablet + milk & 1.5 & 21.1 \\
2. & Fe tablet + Vit. C & 1.3 & 15.2 \\
3. & Fe tablet + mineral water (control) & 1.29 & 15.1 \\
\hline & Average & 1.36 & 17.1 \\
\hline
\end{tabular}

Based on the table above, it can be conclude that the group of respondents who received the highest number in the treatment is on the provision of Fe tablet + milk 21.1 $\%$, Fe tablet + Vitamin $\mathrm{C} 15.2 \%$, and Fe tablets + mineral water $15.1 \%$. Thus, the average gain of Hemoglobin $(\mathrm{Hb})$ level in blood is $17.1 \%$.

The Data Normality Test

Researchers tested the normality of the data. This test is conducted to make sure that the data that will be analyzed is suitable to the analysis method, which is one way anova. The normality of the test can be seen in the table below:

Tabel 5 Results of The Data Normality Test in Comparative Study: Distributing Fe Tablet and Fe Tablet Combined with Milk and Vitamin C To SMPN 09 Students in Cirebon

\begin{tabular}{llccc}
\hline \multicolumn{1}{c}{ Testing } & & Free_Test & Post_Test & Hb Gain \\
\hline \multirow{2}{*}{ N } & & 27 & 27 & 27 \\
\multirow{2}{*}{ Normal Parameters ${ }^{\mathrm{a}, \mathrm{b}}$} & Mean & 9.5926 & 10.9519 & 1.3593 \\
& Std. Deviation & 1.80020 & 1.29210 & 1.29800 \\
\hline
\end{tabular}




\begin{tabular}{llccc}
\hline Most Extreme & Absolute & .175 & .126 & .154 \\
Differences & Positive & .110 & .078 & .154 \\
Kolmogorov-Smirnov Z & Negative & -.175 & -.126 & -.078 \\
Asymp. Sig. (2-tailed) & & .912 & .655 & .801 \\
\hline
\end{tabular}

a. Test distribution is Normal.

b. Calculated from data.

Based on the table above, it can be seen that the Asymp value. Sig (2-tailed) shows the greater value than 0.05 . thus, it can be concluded that the data in this research is normally distributed.

Descriptive Analysis Results

Tabel 6 The Descriptive Analysis Results in Distributing Fe Tablet and Fe Tablet Combined with Milk, Vitamin C, Mineral Water (control) to SMPN 09 Students in Cirebon

\begin{tabular}{|c|c|c|c|c|c|c|c|c|}
\hline \multirow[t]{2}{*}{ Treatment Group } & \multirow[t]{2}{*}{$\mathbf{N}$} & \multirow[t]{2}{*}{ Mean } & \multirow{2}{*}{$\begin{array}{c}\text { Std. } \\
\text { Deviation }\end{array}$} & \multirow{2}{*}{$\begin{array}{l}\text { Std. } \\
\text { Error }\end{array}$} & \multicolumn{2}{|c|}{$\begin{array}{c}\text { 95\% Confidence } \\
\text { Interval for } \\
\text { Mean } \\
\end{array}$} & \multirow{2}{*}{$\begin{array}{c}\text { Mini } \\
\text { mu } \\
\text { m }\end{array}$} & \multirow{2}{*}{$\begin{array}{l}\text { Maxi } \\
\text { mum }\end{array}$} \\
\hline & & & & & $\begin{array}{l}\text { Lower } \\
\text { Bound }\end{array}$ & $\begin{array}{l}\text { Upper } \\
\text { Bound }\end{array}$ & & \\
\hline Fe tablet + Milk & 9 & 1.4889 & 1.71861 & .57287 & .1679 & 2.8099 & -.80 & 4.40 \\
\hline Fe tablet + Vit C & 9 & 1.3000 & 1.18004 & .39335 & .3929 & 2.2071 & -.10 & 4.00 \\
\hline $\begin{array}{l}\text { Fe tablet + Mineral } \\
\text { Water }\end{array}$ & 9 & 1.2889 & 1.04934 & .34978 & .4823 & 2.0955 & .00 & 2.70 \\
\hline Total & 27 & 1.3593 & 1.29800 & .24980 & .8458 & 1.8727 & -.80 & 4.40 \\
\hline
\end{tabular}

Based on the table above, it can be concluded that the hemoglobin level in group of $\mathrm{Fe}$ tablet and Milk is the highest, which is 1.71861 .

Comparative Analysis Results

Tabel 7 The Comparative Analysis Results in Distributing Fe Tablet and Fe Tablet Combined with Milk, Vitamin C, Mineral Water (control) to SMPN 09 Students in Cirebon

\begin{tabular}{lrrrrr}
\hline \multicolumn{1}{c}{ Testing } & \multicolumn{1}{c}{$\begin{array}{c}\text { Sum of } \\
\text { Squares }\end{array}$} & Df & Mean Square & F & \multicolumn{1}{c}{ Sig. } \\
\hline Between Groups & .227 & 2 & .114 & .063 & .939 \\
Within Groups & 43.578 & 24 & 1.816 & & \\
\hline Total & 43.805 & 26 & & & \\
\hline
\end{tabular}


Based on the table above, it can be seen that the sig. value in the test was 0.939 greater than 0.05 . Thus, it can be concluded that there was no significant difference between the treatment group of Fe tablet + Milk, Fe tablets + Vitamin $\mathrm{C}$, and Fe tablets + mineral water (Control).

\section{DISCUSSION}

\section{Fe tablets and milk}

The results showed that the hemoglobin of respondents who were given Fe tablets and milk, have increased of $1.5 \mathrm{~mm} / \mathrm{dl}(21.2 \%)$. Wibowo (2010) said that the patients who were treated with iron treatment gave a good response because the reticulocyte rises in the first week and reached the peaks on the $10^{\text {th }}$ day. It is getting normal again after the $14^{\text {th }}$ day, followed by the gain of hemoglobin for $0.15 \mathrm{~g} /$ day per 2g/dl after 3-4 weeks. Hemoglobin becomes normal after 4-10 weeks. Thus, milk consumption can increase the iron level in the body. The iron composition in milk (4mg/40gr) is strongly associated with homologous proteins with ferritin, which is called lactoferrin. It helps the body to transport iron to receptors in intestine and is associated with its absorption. Lactoferrin in baby's body can also act as antimicrobial that prevent the intestinal infection (Devlin, 1992). Therefore, young women are encouraged to consume milk to prevent the anemia since it also impacts the reproduction system.

According to AKG 2013, the need of iron for men aged 10-12 years old is 13 $\mathrm{mg} /$ day, while women aged 10-12 years is $20 \mathrm{mg} / \mathrm{day}$. The results of this research showed that the iron intake from normal samples is ranged from 3 to $32.4 \mathrm{mg} /$ day to 
the average of $10.9 \pm 4.5 \mathrm{mg} /$ day. Meanwhile, the iron intake from obesity samples is ranged from 4.9-43.2 $\mathrm{mg} /$ day. The average is higher than the normal sample, which is $12.04 \pm 6.4 \mathrm{mg} / \mathrm{day}$. Then, based on figure 5 , most iron sufficiency level in the two sample groups were classified as lack even though the percentage is higher than the normal samples. This research has not observed the frequency of samples in iron food consumption and iron supplement. Thus, the cause of sufficient level of iron in the substance cannot be certainly known.

\section{Fe tablets and vitamin $\mathrm{C}$}

The research has shown that the hemoglobin of respondents who were given Fe tablets and vitamin $\mathrm{C}$, have increased of $1.3 \mathrm{~mm} / \mathrm{dl}(15.2 \%)$. This results is in line with the results of Romlah (2016) that the absorption of iron in the form of non-heme increase four times it is combined with vitamin $\mathrm{C}$. Vitamin $\mathrm{C}$ has an important role in transferring iron in plasma to liver ferritin. In fact, the food that contain of animal protein, folic acid, and ascorbic acid can help the iron absorption in the body.

High-protein nutritious food has a high animal protein, such as in meat, fish, chicken, liver. The high-protein nutritious food can also be found in vegetables, such as dark green vegetables, beans, and soy. The vitamin $\mathrm{C}$ can also be found in vegetables and fruits, such as katuk leaves, cassava leaves, spinach, guava, tomatoes, oranges, and pineapple (Olivia, 2004).

The absorption of iron is influenced by animal protein from vitamin $\mathrm{C}$. Meanwhile, the substance that inhibit the absorption itself can be found in coffee, tea, salt, calcium, and magnesium, since those substances bind the iron and decrease the production of hemoglobin (Tarwono and Wasnidar, 2007). 
The treatment that can be given to adolescents who are in periods and have anemia is $3 \times 100 \mathrm{mg}$ of vitamin $\mathrm{C}$ per day. The vitamin $\mathrm{C}$ is needed to improve iron absorption in the body. Increasing the consumption of vitamin $\mathrm{C}$ as much as 25,50 , 100, and $250 \mathrm{mg}$ can increase the iron absorption by 2, 3, 4, and 5 times (Wirakusumah, 1999).

\section{Fe tablets and mineral water (control group)}

From this research, it can be concluded that the hemoglobin of respondents who were given Fe tablets and mineral water, have increased of $1.29 \mathrm{~mm} / \mathrm{dl}(15.1 \%)$. The young woman in periods and have anemia were given Fe tablets and anthelmintic. The iron composition in women body that has experienced menstruation is more than men. The iron loss caused by menstruation is $28 \mathrm{mg} /$ period. The iron reserves in women are fewer (300mg) than men (1000mg).

If the iron deficiency occurred in the body, the first thing to keep its composition in the body is by consuming the iron reserves. Iron may continue to decline if it is not treated immediately, especially for women since they lack of iron and it can cause anemia (Wirakusumah, 1999).

Hemoglobin is a main component of erythrocytes that carry oxdant carbondioxide. The red color in blood is caused by hemoglobin $(\mathrm{Hb})$, a complex protein substance that contain of proteins, globulins, and non-protein component called heme. Heme is composed of a circular compound called porphyrin whose center is occupied by ferrous metal $(\mathrm{Fe})$. Heme is iron-porphyrin compounds, while hemoglobin is a complex compound of globin and heme (Masrizal, 2007). The main component of hemoglobin is iron. The body approximately contains of 4.5 grams of iron, in which 
$73 \%$ of them are in hemoglobin, $2 \%$ in the muscle and enzyme, and the remaining $25 \%$ is stored as reserve in the liver, bone marrow, and spleen (Sampoerna, 2004).

The needs of iron for adolescent continue after menstruation, at the of 14 . Adolescents need 30\% iron more than the mothers because the iron loss through the menstruation is $29 \mathrm{mg}$ per month (Briawan, 2013).

The analysis result shows that there is no significant differences on the gain of SMPN 09 Cirebon students' hemoglobin when the Fe tablets are combined with milk, vitamin $C$, and mineral water. The value of the test is 0.0939 greater than 0.05 .

It can be explained that the the consumption of Fe tablets can increase the hemoglobin levels. The results of Rachmadianto study (2014) at SLTPN I Donorojo, Pacitan showed that the consumption of Fe tablets can decrease the mild anemia for about $20,26 \%$ of 104 students who suffered it. the value of $p=0.026,<0,05)$. Similar result is also found in the study Ummah, Sulistiyowati, Permadi (2010) at SMP Muhammadiyah 21 Brangsi, Laren Lamongan, that the level of hemoglobin is increased $94,7 \%$ (18 students). The test was conducted usingT-test and the result shows that $\mathrm{t}$ arithmetic is located beyond -1.740 to +1.740 , whereby $\mathrm{P}<0.05$. It means that there is a difference in the average level of hemoglobin before and after the consumption of $\mathrm{Fe}$ tablets. There is an effect of the consumption to the improvement of hemoglobin levels.

In this research, the addition of milk and vitamin $\mathrm{C}$ also increase the $\mathrm{Hb}$ level, which is $21,1 \%$ and $15,1 \%$ compared to the consumption of Fe only $(15,1 \%)$. It is in line with the theory that the consumption of milk and vitamin $\mathrm{C}$ can increase iron absorption in the body. Declin (1992) stated that milk consumption can increase iron in the body. The iron in milk ( $+4 \mathrm{mg} / 40 \mathrm{gr})$ help the body in transporting iron to the receptors in intestine, which is associated with its absorption. In addition, the 
consumption of vitamin $\mathrm{C}$ can also increase the iron absorption in the body (Wirakusumah, 1999). Comparatively, the addition of mil and vitamin $\mathrm{C}$ in Fe tablets consumption did not show a significant impact on $\mathrm{Hb}$ levels of students who were given Fe tablets only. It happened because the amount of milk and vitamins given is not enough.

\section{CONCLUSION}

The "Comparative Study: Distributing Fe Tablet and Fe Tablet Combined with Milk and Vitamin C To SMPN 09 Students in Cirebon" has been conducted. There are several aspects that can be concluded from this research, which are:

1. The respondents who were given Fe tablet + Milk had increased an average hemoglobin $(\mathrm{Hb})$ level for about $1.5 \mathrm{~mm} / \mathrm{dl}$, respondents who were given Fe tablet

+ Vitamin $\mathrm{C}$ had increased an average hemoglobin $(\mathrm{Hb})$ for about $1.3 \mathrm{~mm} / \mathrm{dl}$, and respondents who were given $\mathrm{Fe}+$ mineral water (control) had increased an average hemoglobin $(\mathrm{Hb})$ for about $1.29 \mathrm{~mm} / \mathrm{dl}$.

2. The proportion of respondents given Fe tablets + Milk is $21,1 \%$, Fe tablet + Vitamin $\mathrm{C}$ is $15.2 \%$, and Fe tablet + mineral water is $15.1 \%$.

3. there is no significant differences among the treatment groups of Fe tablet + milk, Fe tablet + Vitamin C, and Fe tablet + mineral water. The value of the test is 0.0939 greater than 0.05 .

Community Health Center is the center of public health services in society and also in school. Thus, this public health service is hopefully contributed in:

1. Improving the distribution of Fe tablets to students to prevent anemia, 
2. Improving the cross-sectoral cooperation in programing the distribution of Fe tablet itself, especially to female students in the school.

\section{REFERENCES}

Almatsier, S. 2002. Prinsif Gasar Ilmu Gizi. Jakarta. PT Gramedia Pustaka Utama

Arisman, MB. 2004. Gizi dalam Daur Kehidupan. Jakarta. Buku Kedokteran. EGC

Bakta, I.M. 2007.Buku Ajar Ilmu Penyakit Dalam. Jakarta. FK UI.

Briawan, D. 2013. Masalah Gizi Pada Remaja Wanita. Jakarta. EGC.

Depkes RI. 2005. Anemia Gizidan Tablet Tambah Darah untuk Wanita Subur. Jakarta. Direktorat Gizi Masarakat

Depkes RI. 2006. Surat Keputusan Menteri Kesehatan Nomor: 424/MENKES/SK/VI, 2006, Pedoman Pengendalian Cacingan, Jakarta. Departemen Kesehatan.

Devlin, T.M. 1992. Textbook of Biochemistry With Correlation. Third. New York. John Willy \& Sons Inc. Publication.

Djaeni S.A. 2004. IlmuGizi Untuk Mahasuswa dan Profesi di Indonesia.Jakarta : Dian Rakyat.

E.M.DeMaeyer. 1995. Pencegahan Dan Pengawasan Anemia DefisiensiBesi. Jakarta. WidyaMedika.

Haryati, L. 2014. Kegemukan. Obesitas Dan PrestaiBelajar. Bogor. Departemen Gizi Masyarakat Fakultas Ekologi Manusia Institut Pertanian Bogor

Heryati, L. 2014. Kegemukan, Anemia Dan Prestasi Belajar Siswa SD Di Kota Bogor. Departemen Gizi Masyarakat Fakultas Ekologi Manusia Institut Pertanian Bogor

Kusmiran, E. 2011.Kesehatan Reproduksi Remaja dan Wanita. Jakarta. Salemba Medika

Lubis, B. 2008. PerbedaanResponHematologi Dan PerkembanganKognitifPadaAnak Anemia DefisiensiBesiUsiaSekolahDasar Yang MendapatTerapiBesiSatu Kali Dan Tiga Kali Sehari. Sari Pediatri. 10(3):184-9.

Masrizal. 2007. JurnalKesehatanMasyarakat. Padang. Program StudiIlmuKesehatanMasyarakat FK UNAND. 
Muchtar, M. 2000. Status Anemia Dan Prestasi Belajar Siswi SMUN I Kuala Kapuas Kabupaten Kapuas.Skripsi.Bogor :Institut Pertanian Bogor.

Olivia, dkk.2004. Seluk Beluk Food Suplement. Jakarta. PT. GramediaUtama

Oppusunggu, R. 2009. Pengaruh Pemberian Tablet Tambah Darah (Fe) Terhadap Produktivitas Kerja Wanita Pensortir Daun Tembakau Di Pt. X Kabupaten Deli

Serdang.Diunduhdarihttp://repository.usu.ac.id/bitstream/123456789/6889/1/ 09E01321.pdf. Tanggal 28 Okt 2016

Pojok bandung.com.2016. Marak Remaja Putri Anemia, Dinkes Akan Bagikan Tablet Ini.Diunduh http : // bandung.pojoksatu.id / read / 2016 / 08 / 04 / marak remaja-putri - anemia - dinkes - akan - bagikan - tablet - ini/ padatanggal 4 Agustus.2016

Purba, R.T.2007. Perbandingan Efektivitas Terapi Besi Intravena dan Oral pada Anemia Defisiensi Besi dalam Kehamilan.Jakarta : FKUI

Rachmadianto, N.T. 2014. Epektifitas Pemberian Tablet Tambah Darah Terhadap Kadar Hb Siswi Sltpn Donorojo Kecamatan Donorojo Kabupaten Pacitan. Diunduh dari http://eprints.ums.ac.id/32255/12/02.\%20NASKAH\%20PUBLIKASI. pdf.Tanggal 28 Okt 2016

Romlah, S. Hadi, H. 2016. Suplemen obat cacing, sirup, fe dan vitamin $C$, meningkatkan kadar $\mathrm{Hb}$ dan Status gizibalita di Kupang. Edisi March 2016DOI: 10.21927/ijnd.2013.1(1).1-6

Sampoerna, T. 2004. Kiat Mengenal Penyakit dan Obatnya. Jakarta :Progres

Savitri, S. 1995. Studi Anemia pada Anak Sekolah Dasar. Majalah Kedokteran Indonesia. Vol. No.5

Simatupang, B. 2011.AGB (Anemia GiziBesi). Jakarta. Makara.

Sopiyudin, D. 2004. Statistika Untuk Kedokteran dan Kesehatan.Jakarta : PT. ARKANS

Sudoyo, A.W. 2007. Buku Ajar Ilmu Penyakit Dalam.Jakarta : FKUI

Supariasa, dkk.2001. Penilaian Status Gizi.Jakarta : EGC.

Tarwono, Wasnidar, (2007), Anemia pada ibu hamil konsep dan piñata laksanaanya, Jakarta: Trans info media

Wibowo, M.F.A. 2010. Pengaruh Suplementasi Tablet Besi Dan Vitamin C Terhadap Peningkatan Kadar Hemoglobin Pada Siswa Kelas Vi SdnKlego 01 Kota 
Badriah: Comparative Study: Distributing Fe Tablet and Fe Tablet Combined

Pekalongan. Diunduhdarihttp://lib.unnes.ac.id/2478/1/3435.pdf. Tanggal 28 Okt 2016

Wirakusumah, E.S. 1999. Perencanaan Menua Anemia Giz iBesi. Jakarta. TrubusAgriwidya. 